\title{
EVALUATION OF GROWING STOCK, BIOMASS AND SOIL CARBONS AND THEIR ASSOCIATION WITH A DIAMETER: A CASE STUDY FROM A PLANTED CHIR PINE (PINUS ROXBURGHII) FOREST
}

\author{
KHAN, I. ${ }^{1 \#}-$ HAYAT, U. ${ }^{2 \# *}-$ MUJAhID, A. ${ }^{3}-$ MAJID, A. ${ }^{1}-$ ChaUdhary, A. ${ }^{4}-$ BADSHAH, M. T. ${ }^{3}$ \\ - HUANG, J. ${ }^{1}$ \\ ${ }^{1}$ School of Soil and Water Conservation, Beijing Forestry University, 100083 Beijing, China \\ (e-mails: inamkhan.1325@gmail.com,abdulmajid3637@gmail.com, \\ jiankunhuang@yahoo.com)
}

${ }^{2}$ Sino-France Joint Laboratory for Invasive Forest Pests in Eurasia, School of Forestry, Beijing Forestry University, 100083 Beijing, China

${ }^{3}$ Department of Forest Management, School of Forestry, Beijing Forestry University, 100083 Beijing, China

(e-mails: forester37101@outlook.com,badshahgi90@gmail.com)

${ }^{4}$ Department of Forestry and Range Management, University of Agriculture, Faisalabad, Pakistan

(e-mail: aroojch533@gmail.com)

\#These authors have contributed equally to this work

*Corresponding author

e-mail: oomarcassi6116@gmail.com; phone: +92-30-4429-1135, + 86-188-1139-2885

(Received 20 $0^{\text {th }}$ Nov 2020; accepted 27 Jan 2021)

\begin{abstract}
The statistical association between the capacity for carbon sequestration and planted Pinus roxburghii tree diameter classes are not recorded in Pakistan. Through the forest inventory approach, a comprehensive study was conducted in planted P. roxburghii forest in Pakistan's Swat Hindu Kush area to determine the carbon stock (CS) of a live tree, forest floor and soil (SOC) and their association with three diameter classes $(6-22,23-40,41-60 \mathrm{~cm})$. The results specified that stem density had a polynomial relation with the diameter $(\mathrm{R} 2=-0.54)$, while tree height had a linear relationship with the diameter $(\mathrm{R} 2=0.73)$. Association of tree volume, stem biomass, total tree biomass with basal area against diameter classes were positively linear $[(\mathrm{R} 2=0.86,0.80,0.80)$ for DBH $(41-60 \mathrm{~cm})]$. As the diameter increases, grass CS reduced while litter and deadwood CS increased significantly. Association of diameter classes with (SOC) at various depths was negatively linearly correlated [R2 $=-0.99$; for DBH $(41-60 \mathrm{~cm})]$, while the topsoil layer $(0-20 \mathrm{~cm}) \mathrm{SOC}$ rose significantly with increase in diameter class. With the increase in tree diameter, the tree age increased definitively $(\mathrm{R} 2=0.99)$. An increase in diameter class ultimately increased CS amount, and the trend was as follows: live tree > soil > forest floor. This study significantly demonstrated the diameter relationship with the tree, forest floor and soil CS of planted P. roxburghii forest.
\end{abstract}

Keywords: Pinus roxburghii, afforestation, inventory, biomass carbon, carbon stock (CS), soil bulk density (SBD), SOC, Swat, Pakistan

\section{Introduction}

Global climate change is a burning issue within the scientific community because of accelerating carbon dioxide concentration in the atmosphere due to various human activities. The rapid social activities and industrialization increase the carbon contents 
in the atmosphere, causing global warming and climate change (Sharma et al., 2011). According to the Intergovernmental Panel on Climate Change report 2018, the Earth's average temperature by $1.5^{\circ} \mathrm{C}$ until now is considered to accelerate probably to $3{ }^{\circ} \mathrm{C}$ increase of the end of this century (Delmotte et al., 2018).

According to the Kyoto Protocol, the UNFCC acknowledges the forest, a potential tool to palliate and stabilize the carbon concentration (Ahmad et al., 2014b). Forest restoration is an essential tool that significantly countervails atmospheric carbon emanations (Laurance, 2007). Unfortunately, due to the forest restoration scheme's vague apprehension, the real latent of forest biomass has been halted (Holl and Zahawi, 2014). Planted forests are essential mitigation tools for the climate. Many studies have revealed that thick plantations have higher carbon stocks (Bonner et al., 2013), while some reported that the carbon stocks ratio is higher for naturally regenerated secondary forests (Chrsquo et al., 2011). However, forest carbon accumulation capacity is higher for thick planted forests than regenerated forests stand, which also rendered the application of prudish silvicultural management (Baishya et al., 2009). Forest soil can also be used as a significant sink for storing an immense volume of carbon in the form of soil organic materials that can help mitigate global climate change (Ullah et al., 2019).

As a core proposition, afforestation enhances the earth's organic carbon stock by growing plant litter in the soil. Soil carbon sequestration is a long-term, cost-effective and efficient approach for enhancing soil characteristics and quality (Li et al., 2013). Tree plantations had an ambivalent role in ecosystem services in the past. Their production function has functioned the growing demands for wood products efficiently (Bauhus et al., 2010). Many ecological resources improved where plantations were developed on the deteriorated or former property (Cossalter and Pye-Smith, 2003).

The capacity of forest plantations to store carbon throughout the Globe is about $3.8 \%$ (FAO, 2006), but overall, this small percentage of storage capacity plays a vital role in mitigating and fight against climate change (Canadell et al., 2007). Generally, natural forests have more potential for storing biomass than forest plantations per hectare (Pan et al., 2004). However, natural forests have decreased from $46 \%$ to $28 \%$ of the Earth's terrestrial ecosystems (Winjum and Schroeder, 1997). The measurement of biomass and carbon stock is essential to calculate the forest carbon potential in the region. The evaluation of biomass and carbon stock needs forest inventory data in sampled plots of different pools, i.e., aboveground biomass, belowground biomass, soil organic carbon, deadwood carbon and forest floor (litter/twigs) (Nizami et al., 2009; Sullivan et al., 2017).

Previously, different types of study have been conducted for the estimation of carbon stock in different forest types of Pakistan (Nizami, 2012; Ahmad and Nizami, 2015; Ahmad et al., 2014a; Amir et al., 2019); most of the study in Pakistan have been conducted in the natural forests of Pakistan. Some of the reviews regarding forest carbon in planted Bela forests and irrigated plantation in Punjab province, Pakistan is available (Saeed et al., 2016; Arif et al., 2017). There is a lack of information to estimate annual carbon sequestration potential in planted Chir pine forests in Pakistan.

For the first time in Pakistan, this study outlines the carbon stock in respective carbon pools in the planted Chir pine forests. We hypothesized that the young planted conifer forest and its soil are essential sources to sink and store the atmosphere's carbon, just like the natural forest. The main aims of the present study were to determine the tree biomass and carbon stock and their association with three different 
diameter classes $(6-22,23-40,41-60 \mathrm{~cm})$ of planted $P$. roxburghii forest; to determine the forest cover (grasses, litter and deadwood) carbon stock and their association with three different diameter classes, to determine the soil carbon stock (SOC) and their association with three different diameter classes at various depths (0-20, 21-40, 41-60, 61-80 cm); and to find out the association of tree diameter with tree age.

\section{Materials and methods}

\section{Study zone}

The current study was carried out in Dureshkhela village of district swat (Latitude and Longitude $34.7933^{\circ} \mathrm{N}$ and $72.2889^{\circ} \mathrm{E}$, respectively) KPK, Pakistan (Fig. 1; Table A1), from April 2017 to May 2017. The elevation ranges from 914.4 to $1118.6 \mathrm{~m}$. The area receives $1000-1200 \mathrm{~mm}$ annual average precipitation, as recorded by Saidu Sharif metrological station. The minimum and maximum average temperatures vary from 5 to $38{ }^{\circ} \mathrm{C}$, as evident from the data recorded in December and June by the meteorological station of Saidu Sharif; mainly area occupied by the mountain ranges and weather is just like the closest area "Kumrat valley, Hindu Kush Region, Pakistan" (Ahmad and Nizami, 2015).

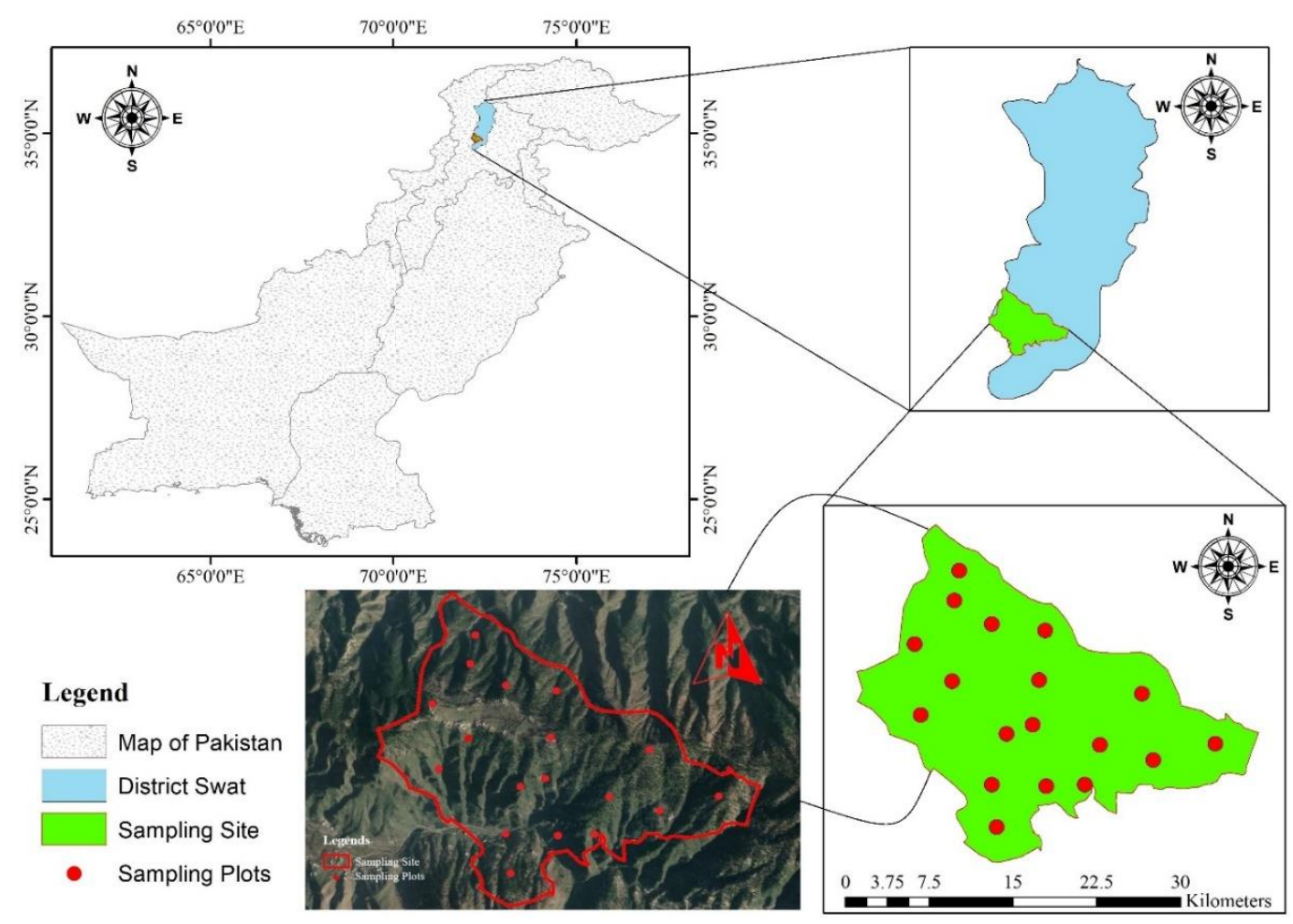

Figure 1. Location of study area of Swat in Northwest Pakistan

\section{Research design and data source}

The data was collected through forest inventory (Fig. 2). 18 square-shaped sampling plots ( 0.1 ha each) were randomly selected to cover the total area of 262 ha. The data collected from those sampling plots were tree height $(\mathrm{m})$ using 'Spiegel relay scope,' DBH $(\mathrm{cm})$ using 'Vernier caliper,' latitude and longitude of each plot using 'GPS device.' 
For investigating soil organic carbon, by following the IPCC guideline, soil samples from the four different layers of soil $(0-20 \mathrm{~cm}, 21-40 \mathrm{~cm}, 41-60 \mathrm{~cm}$ and $61-80 \mathrm{~cm})$ with a thickness level of $20 \mathrm{~cm}$ each were collected using soil auger. For soil samples analysis for finding the soil organic carbons, the core method was adopted (Gross and Harrison, 2018), and analysis was carried out in the "Soil Testing and Conservation Lab, Rawalpindi, Pakistan."

For investigating shrub, herb, grasses, deadwood, and litter layer biomass, the subplot or quadrates of $1 \mathrm{~m} \times 1 \mathrm{~m}$ were selected, and the data was recorded. Samples for each layer were selected and weighed fresh in the field with weighing balance and then placed in plastic bags and later dried in the oven at $72{ }^{\circ} \mathrm{C}$ for $48 \mathrm{~h}$.

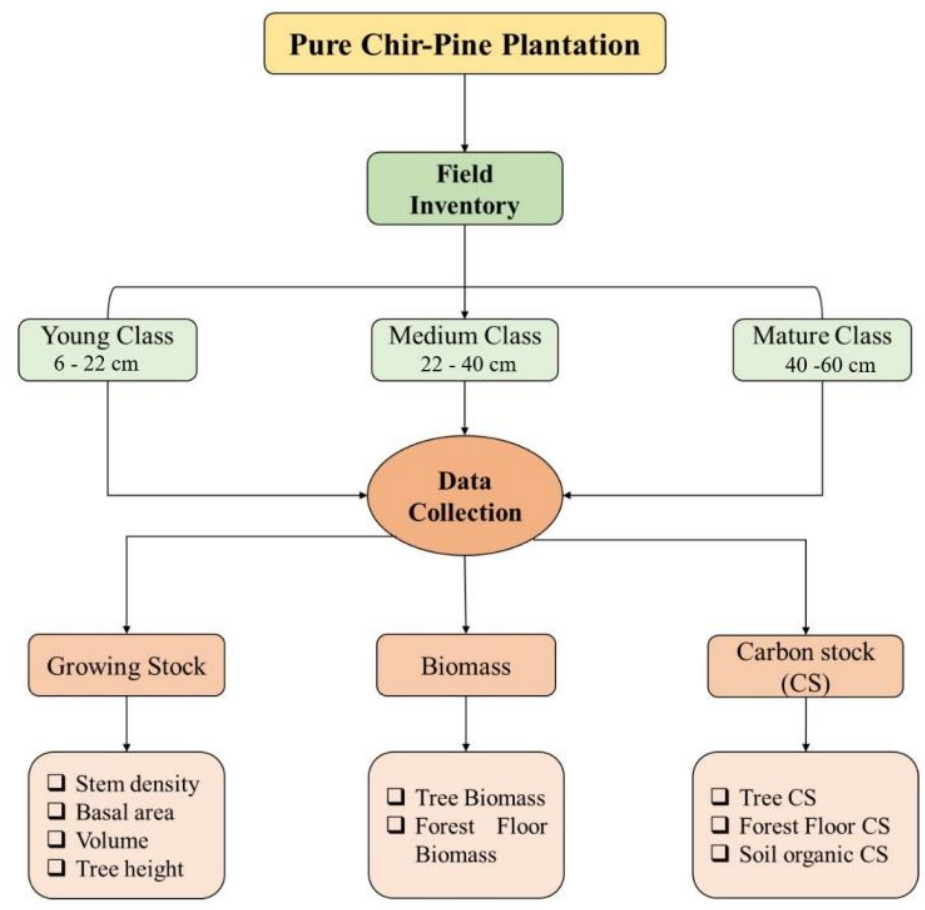

Figure 2. The layout of the research design

\section{Growing stock and biomass calculation}

The tree volume $\left(\mathrm{m}^{3}\right)$ was determined by using the following formula (Philips, 1994):

$$
\text { Tree volume }\left(m^{3}\right)=\left[\left(\frac{\pi}{4}\right) \times d^{2} \times h \times f\right]
$$

The stem biomass of identified tree species in the area was calculated from the following formula:

$$
\text { Stem biomass }=\text { Volume }\left(\mathrm{m}^{3}\right) \times \text { Basic wood density }\left(\mathrm{kgm}^{-3}\right)
$$

Overall, tree biomass was determined using the following formulas:

$$
A G B\left(t h a^{-1}\right)=\text { Stem biomass }\left(t h a^{-1}\right) \times B E F
$$




$$
\begin{gathered}
B G B\left(t h a^{-1}\right)=A G B\left(t h a^{-1}\right) \times R \\
\text { Total tree biomass }\left(t h a^{-1}\right)=A G B+B G B
\end{gathered}
$$

where: $\mathrm{AGB}=$ above ground biomass; $\mathrm{BGB}=$ below ground biomass; $\mathrm{BEF}=$ biomass expansion factor; $\mathrm{R}=$ root to shoot ratio.

The leaves, branches, twig role in overall above-ground biomass was assessed by biomass expansion factor (BEF) of the corresponding tree species. According to the literature, the BEF value for $P$. roxburghii used recently was 1.51 (Amir et al., 2019).

\section{Carbon stocks calculation}

The carbon stock conversion factor (0.5) (Amir et al., 2018) was used to convert total biomass to total carbon stock. This adaptation aspect has been used extensively around the Globe.

The total carbon stock was determined by using the following formula (Nizami, 2012; Ahmad et al., 2014a):

$$
\text { Total carbon stock }\left(t C h a^{-1}\right)=\text { Total Tree Biomass }\left(t h a^{-1}\right) \times 0.5 \text { (Eq.4) }
$$

Quantities of understory vegetation biomass: The understory vegetation such as shrubs, herbs, and grasses were collected from each sample plot. Then the fresh weight of all samples $(\mathrm{kg})$ was documented, and the average weight was taken and extrapolated to calculate the current weight of the whole plot. The collected samples were dried at $72{ }^{\circ} \mathrm{C}$ for $48 \mathrm{~h}$ (Roy et al., 2001).

\section{Calculation of soil bulk density (SBD)}

Soil bulk density in each age group was determined from the soil sample's weight and known soil core volume according to the given Equation.

$$
\text { Soil Bulk Density }\left(\mathrm{g} \mathrm{cm}^{-3}\right)=\frac{\text { weight of soil sample }(\mathrm{g})}{\text { volume soil core }\left(\mathrm{cm}^{\mathrm{s}}\right)}
$$

\section{Calculation of soil carbon ( $\mathrm{C} / \mathrm{ha}$ )}

The bulk density ( $\mathrm{g} \mathrm{cm}-3)$ of soil samples was measured individually. The oxidizable organic carbon method (Walkley and Black, 1934) was used to find out soil carbon using the following formula (Pearson et al., 2007):

$$
\text { Soil carbon }\left(t C h a^{-1}\right)=\operatorname{SBD}\left(\mathrm{g} \mathrm{cm}^{-3}\right) \times \operatorname{SOC}(\%) \times \operatorname{SHT}(m) \times 100 \text { (Eq.6) }
$$

where: SBD $=$ Soil Bulk Density $\left(\mathrm{g} / \mathrm{cm}^{3}\right), \mathrm{STH}=$ Soil horizon thickness $(\mathrm{m})$.

For statistical analysis, we used Statistics (8.1 version), Origin (9.0 version), Excel pro professional (2016 version) software; for graphs and figures, Excel pro professional (2016 version) was used. Analysis of variance (ANOVA) was used to calculate the significant level at $(\mathrm{P}<0.05, \mathrm{P}<0.01, \mathrm{P}<0.001)$ respectively, Tukey HSD post-hock test was used to indicate the significane for mean biomass and carbon stock values. A regression model (Linear, Polynomial) was used to illustrate the relationship between different factors for tree biomass and carbon stock. 


\section{Results}

\section{Growing stock characteristics}

Stand density ranges from 20 to 260 (trees $\left.\mathrm{ha}^{-1}\right)$ in three different diameter classes with the maximum mean value $166.11 \pm 21.63\left(\mathrm{t} \mathrm{ha}^{-1}\right)$ for diameter class $(23-40 \mathrm{~cm})$ and minimum value $33.89 \pm 5.89\left(\right.$ tree $\left.^{-1} \mathrm{a}^{-1}\right)$ for diameter class $(41-60 \mathrm{~cm})($ Table 1). There was polynomial linear relationship between $\mathrm{DBH}(\mathrm{cm})$ and stand density (tree $\mathrm{ha}^{-1}$ ) $\left(\mathrm{y}=-0.2097 \mathrm{x}^{2}+13.002 \mathrm{x}-69.713 ; \mathrm{R}^{2}=0.54\right)$ was observed (Fig. 3). With the increase in diameter $(\mathrm{cm})$ the tree height $\left(\mathrm{m} \mathrm{ha}^{-1}\right)$ increase positively $(\mathrm{y}=0.3763+1.9855$; $\left.\mathrm{R}^{2}=0.73\right)$ and the maximum mean height was $33.89 \pm 5.89\left(\mathrm{~m} \mathrm{ha}^{-1}\right)$ for DBH $(41-$ $60 \mathrm{~cm}$ ). While mean basal area, stand volume and total tree biomass was also recorded maximum $\left(14.19 \pm 3.67 \mathrm{~m}^{2} \mathrm{ha}^{-1}, 16.69 \pm 4.64 \mathrm{~m}^{3} \mathrm{ha}^{-1}\right.$ and $\left.16.71 \pm 4.51 \mathrm{t} \mathrm{ha}^{-1}\right)$ for DBH $(41-60 \mathrm{~cm})($ Table 1).

Table 1. Distribution of stem density, volume, basal area, and mean height in different diameter classes

\begin{tabular}{c|c|c|c|c|c}
\hline $\begin{array}{c}\text { DBH } \\
(\mathbf{c m})\end{array}$ & $\begin{array}{c}\text { Mean density } \\
\text { (trees/ha) }\end{array}$ & $\begin{array}{c}\text { Mean height } \\
(\mathbf{m} / \mathbf{h a})\end{array}$ & $\begin{array}{c}\text { Mean basal area } \\
\left(\mathbf{m}^{\mathbf{2}} \mathbf{h a}\right)\end{array}$ & $\begin{array}{c}\text { Mean stand } \\
\text { volume }\left(\mathbf{m}^{\mathbf{3}} / \mathbf{h a}\right)\end{array}$ & $\begin{array}{c}\text { Mean total tree } \\
\text { biomass }(\mathbf{t} / \mathbf{h a})\end{array}$ \\
\hline $6-22$ & $38.89 \pm 7.87$ & $5.54 \pm 1.04$ & $1.49 \pm 0.32$ & $0.79 \pm 0.18$ & $0.83 \pm 0.20$ \\
$23-40$ & $166.11 \pm 21.63$ & $13.49 \pm 0.93$ & $7.66 \pm 1.59$ & $6.70 \pm 1.28$ & $7.78 \pm 0.64$ \\
$41-60$ & $33.89 \pm 5.89$ & $16.65 \pm 1.56$ & $14.19 \pm 3.67$ & $16.69 \pm 4.64$ & $12.76 \pm 1.43$ \\
\hline
\end{tabular}
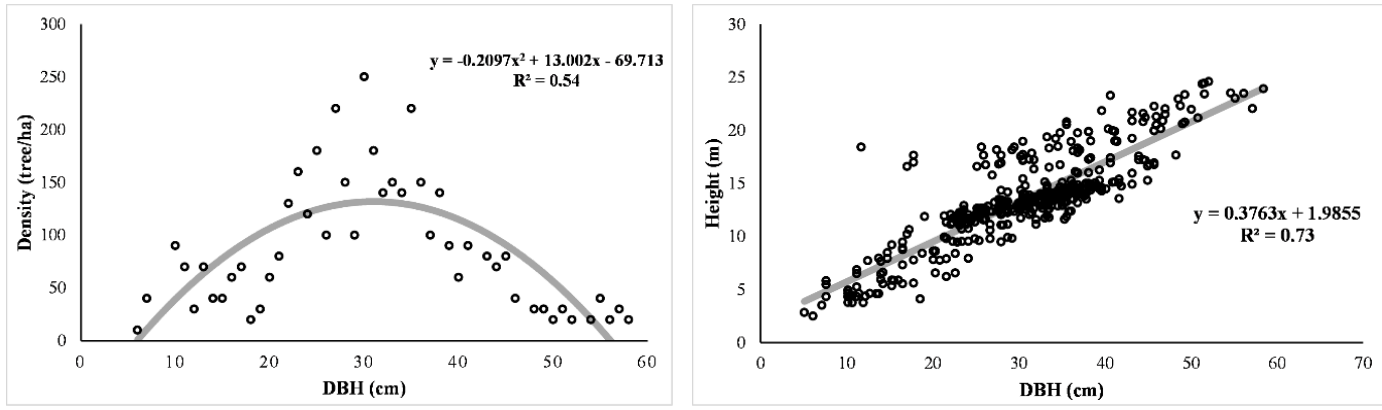

Figure 3. The relation of diameter $(\mathrm{cm})$ with wood density $\left(\right.$ trees $\left.\mathrm{ha}^{-1}\right)$ and height $(\mathrm{m})$

\section{Relationship of different tree growth factors with basal area $\left(\mathrm{m}^{2} / \mathrm{ha}\right)$}

The relation between stem volume, stem biomass, tree carbon stock with the basal area is illustrated in (Fig. 4) for three different diameter classes $(6-22 \mathrm{~cm}, 23-40 \mathrm{~cm}, 41-60 \mathrm{~cm})$.

The association of stem volume $\left(\mathrm{m}^{3} \mathrm{ha}^{-1}\right)$, stem biomass $\left(\mathrm{t} \mathrm{ha}^{-1}\right)$ and total stem biomass $\left(\mathrm{t} \mathrm{ha}^{-1}\right)$ with stem basal area $\left(\mathrm{m}^{2} \mathrm{ha}^{-1}\right)$ were significantly positive for all three diameter classes $(6-22 \mathrm{~cm}, 23-40 \mathrm{~cm}, 41-60 \mathrm{~cm})$. As the basal area $\left(\mathrm{m}^{2} \mathrm{ha}^{-1}\right)$ increases the stem volume $\left(\mathrm{m}^{3} \mathrm{ha}^{-1}\right)$, biomass $\left(\mathrm{t} \mathrm{ha}^{-1}\right)$ and total stem biomass $\left(\mathrm{t} \mathrm{ha}^{-1}\right)$ values also increase positively. The best result of linear regression for stem volume $\left(\mathrm{m}^{3} \mathrm{ha}^{-1}\right)$ against basal area $\left(\mathrm{m}^{2} \mathrm{ha}^{-1}\right)$ was obtained $\left(\mathrm{y}=1.8541 \mathrm{x}-10.682 ; \mathrm{R}^{2}=0.86 ; \mathrm{P}=0.04\right)$ for DBH $(41-60 \mathrm{~cm})$, while the highest significant value was observed $[\mathrm{F}(1,26)=8.22$, $\mathrm{P}=0.008(\mathrm{P}<0.01)]$ for DBH $(6-22 \mathrm{~cm})$. For stem biomass $\left(\mathrm{t} \mathrm{ha}^{-1}\right)$ the maximum linear regression value against basal area $\left(\mathrm{m}^{2} \mathrm{ha}^{-1}\right)$ was $\left(\mathrm{y}=1.2404 \mathrm{x}-7.8463 \mathrm{R}^{2}=0.80\right.$; $\mathrm{P}=0.0008)$ and the highly significant value $[\mathrm{F}(1,30)=13.90, \mathrm{P}=0.0008(\mathrm{P}<0.001)]$ 
were observed for DBH $(41-60 \mathrm{~cm})$. In case of total tree biomass $\left(\mathrm{t} \mathrm{ha}^{-1}\right)$ the best figures of linear regression against basal area $\left(\mathrm{m}^{2} \mathrm{ha}^{-1}\right)$ was $\left(\mathrm{y}=1.4885 \mathrm{x}-9.4155 ; \mathrm{R}^{2}=0.80\right)$ for DBH $(41-60 \mathrm{~cm})$ respectively.
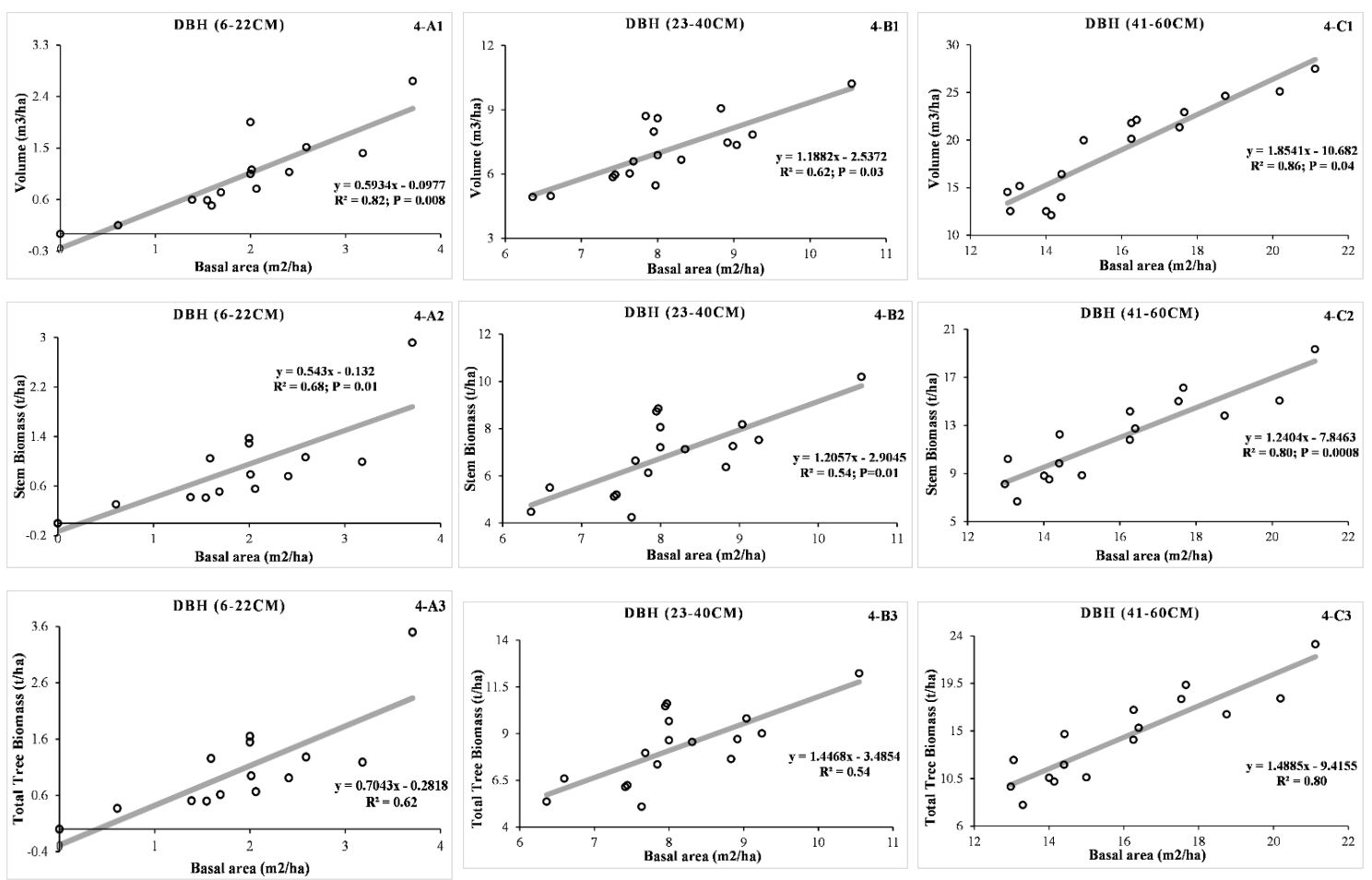

Figure 4. Relationship between the factors, Volume $\left(\mathrm{m}^{3} / \mathrm{ha}\right)$, Stem Biomass $(\mathrm{t} / \mathrm{ha})$, Total Tree Biomass $(\mathrm{t} / \mathrm{ha})$ with the Basal area $\left(\mathrm{m}^{2} / \mathrm{ha}\right)$ for three different diameter classes $(6-22 \mathrm{~cm}, 23$ $40 \mathrm{~cm}, 41-60 \mathrm{~cm})$ at a significant level $(P \leq 0.05, \leq 0.01, \leq 0.001)$

\section{Assessment of forest floor and soil carbon stock}

One of this study's main objectives was to evaluate the forest floor carbon stock and soil carbon stock for three different dia classes.

We observed that stand of small-diameter trees $(6-22 \mathrm{~cm})$ has significantly more grasses cover, which ultimately results in sequestering more carbon $\left(0.1 \pm 0.04 \mathrm{t} \mathrm{C} \mathrm{ha}^{-1}\right)$ compared to the other two diameter classes (Table 2). In the case of litter and deadwood deposits, the quantity of both dead forest floor components was significantly increased with the increase in diameter; therefore, the significantly highest values of litter and dead-wood carbon stock $\left[0.19 \pm 0.06 \mathrm{t} \mathrm{C} \mathrm{ha}^{-1}\right.$ and $0.1 \pm 0.03 \mathrm{t} \mathrm{C}$ ha $^{-1}$ ) were observed for diameter class $(41-60 \mathrm{~cm})$. So the three different diameter classes had significant effect on the amount of grasses carbon stock $[\mathrm{F}(1,4)=13.67, \mathrm{P}=0.02$ $(\mathrm{P}<0.05)]$, litter carbon stock $[\mathrm{F}(1,4)=13.62, \mathrm{P}=0.02(\mathrm{P}<0.05)]$ and dead-wood carbon stock $[\mathrm{F}(1,4)=13.68, \mathrm{P}=0.02(\mathrm{p}<0.05)]$ respectively.

\section{Association of soil bulk density (SBD) and soil organic carbon (SOC) with a diameter}

Overall Soil Bulk density (SBD) in four different soil depths $(0-20 \mathrm{~cm}, 21-40 \mathrm{~cm}$, $41-60 \mathrm{~cm}, 61-80 \mathrm{~cm})$ ranges $\left(0.99-1.16 \mathrm{~g} / \mathrm{cm}^{3}\right)$ for all three diameter classes $(6-22 \mathrm{~cm}$, $23-40 \mathrm{~cm}, 41-60 \mathrm{~cm})$. There was significant difference observed $[\mathrm{F}=53.47, \mathrm{df}=11$, 
$\mathrm{P}=0.0001(\mathrm{P}<0.001)]$ for SBD values at four different soil depths with regards to three different diameter classes (Fig. 5). The SBD in relation with four different soil depths for three diameter classes represented positive linear relationship $\left(\mathrm{y}=0.0011 \mathrm{x}+1.0554 ; \quad \mathrm{R}^{2}=0.84 ; \quad \mathrm{P}=0.0003\right) \quad$ with the highest value $\left(1.16 \pm 0.02 \mathrm{~g} / \mathrm{cm}^{3}\right)[\mathrm{F}(1,6)=14.33, \mathrm{P}=0.009(\mathrm{P}<0.01)]$ at soil depth $(60-80 \mathrm{~cm})$ for diameter class $(41-60 \mathrm{~cm})$. As the soil depth increases the SBD value also increased.

Table 2. Carbon stock of forest floor (grasses, litter and dead wood) and soil ( $\left.t \mathrm{ha}^{-1}\right)$ in planted $P$. roxburghii forest at the level of significance $(P<0.05)$

\begin{tabular}{|c|c|c|c|c|c|c|c|}
\hline \multirow{3}{*}{$\begin{array}{l}\text { DBH } \\
(\mathbf{c m})\end{array}$} & \multirow{3}{*}{$\begin{array}{c}\text { MGCS } \\
(\mathrm{t} \mathrm{C} \mathrm{ha-1)}\end{array}$} & \multirow{3}{*}{$\begin{array}{l}\text { MLCS } \\
\left(\mathrm{t} \mathrm{Cha}^{-1}\right)\end{array}$} & \multirow{3}{*}{$\begin{array}{l}\text { MDwCS } \\
(\mathrm{t} \mathrm{C} \mathrm{ha-1)}\end{array}$} & \multicolumn{4}{|c|}{ SOC (t C ha $\left.{ }^{-1}\right)$} \\
\hline & & & & \multicolumn{4}{|c|}{ Soil depth $(\mathrm{cm})$} \\
\hline & & & & 0 - 20 & $21-40$ & $41-60$ & $61-80$ \\
\hline $6-22$ & $4^{* *}$ & $0.14 \pm 0.04^{* *}$ & $0.04 \pm 0.01^{* *}$ & $2.30 \pm 0.25^{* *}$ & $2.10 \pm 0.21^{* *}$ & $1.93 \pm 0.198^{* *}$ & $1.14 \pm 0.19^{* * *}$ \\
\hline $23-40$ & $0.09 \pm 0.03^{* *}$ & $0.16 \pm 0.05^{* *}$ & $0.07 \pm 0.02^{* *}$ & $2.81 \pm 0.28^{* *}$ & $2.53 \pm 0.26^{* *}$ & $2.12 \pm 0.24^{* *}$ & $1.53 \pm 0.25^{* *}$ \\
\hline $41-60$ & $0.06 \pm 0.01^{* *}$ & $0.19 \pm 0.06^{* *}$ & $0.1 \pm 0.03^{* *}$ & $3.33 \pm 0.36^{* *}$ & $2.78 \pm 0.35^{* *}$ & $2.28 \pm 0.33^{* *}$ & $1.65 \pm 0.32^{* *}$ \\
\hline Sum & $0.25 \pm 0.05$ & $0.49 \pm 0.06$ & $0.21 \pm 0.03$ & $8.44 \pm 0.41$ & $7.41 \pm 0.39$ & $6.33 \pm 0.37$ & $4.32 \pm 0.28$ \\
\hline
\end{tabular}

MGCS $=$ Mean grasses carbon stock, MLCS = Mean litter carbon stock, MDwCS = Mean deadwood carbon stock, SOC $=$ Soil organic carbon stock. $* *$ indicates that according to Tukey (HSD) variables are significant different for different diameter classes

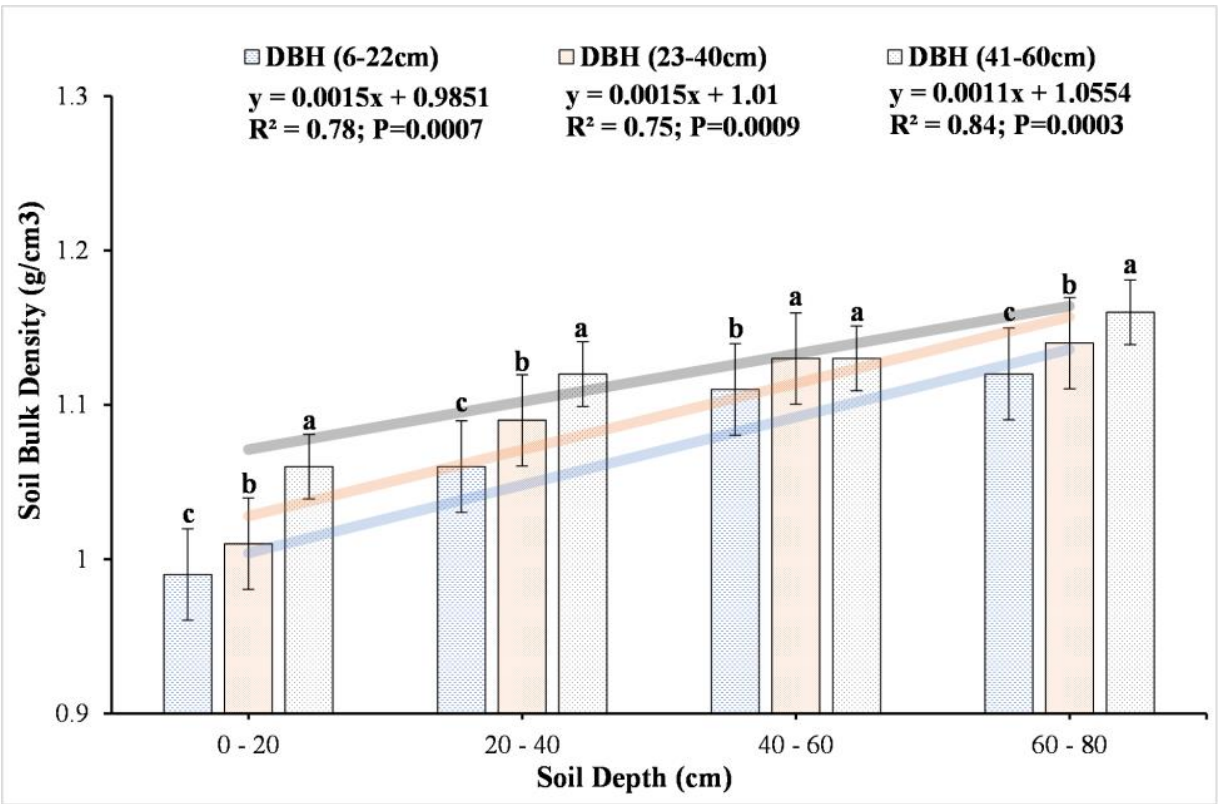

Figure 5. Soil Bulk density in three different diameter classes (6-22, 23-40, 41-60 cm) of planted Pinus roxburghii stand at various depths. The relationship between soil bulk density

and soil depth for different diameter classes are illustrated using linear regression. The different letters $(a, b, c)$ on the bar show significant differences while the same letters on the bar show the non-significant difference between different diameter classes

Soil organic carbon (SOC) in four different soil depths $(0-20 \mathrm{~cm}, 21-40 \mathrm{~cm}, 41-$ $60 \mathrm{~cm}, 61-80 \mathrm{~cm})$ ranges $\left(1.14-3.33 \mathrm{t} \mathrm{C} \mathrm{ha}^{-1}\right)$ for all three diameter classes $(6-22 \mathrm{~cm}$, $23-40 \mathrm{~cm}, 41-60 \mathrm{~cm})$. There was significant difference observed $[\mathrm{F}=45.37, \mathrm{df}=11$, 
$\mathrm{P}=0.0001(\mathrm{P}<0.001)]$ for SOC values at four different soil depths with regards to three different diameter classes (Table 2; Fig. 6). The SOC in relation with four different soil depths for three diameter classes represented negative linear relationship $\left[\left(\mathrm{y}=-0.0277 \mathrm{x}+3.8936, \mathrm{R}^{2}=0.99 ; \quad \mathrm{P}=0.01 \quad(\mathrm{P}<0.05)\right]\right.$ with the highest value $\left(3.33 \pm 0.36 \mathrm{t} \mathrm{C} \mathrm{ha}^{-1}\right)[\mathrm{F}(1,6)=13.52, \mathrm{P}=0.01(\mathrm{P}<0.05)]$ at soil depth $(0-20 \mathrm{~cm})$ for diameter class $(41-60 \mathrm{~cm})$. We observed that diameter class has significant association with soil carbon stock at various depth, as the soil depth increases the SOC value decreases.

Soil organic carbon analysis showed that the young diameter class $(6-22 \mathrm{~cm})$ stand holds minimum soil carbon, but as the diameter increase (41-60) with age, soil carbon holding capacity also increased. The results showed an increasing trend from young diameter class $(6-22 \mathrm{~cm})$ to older diameter class $(41-60 \mathrm{~cm})$ in soil carbon.

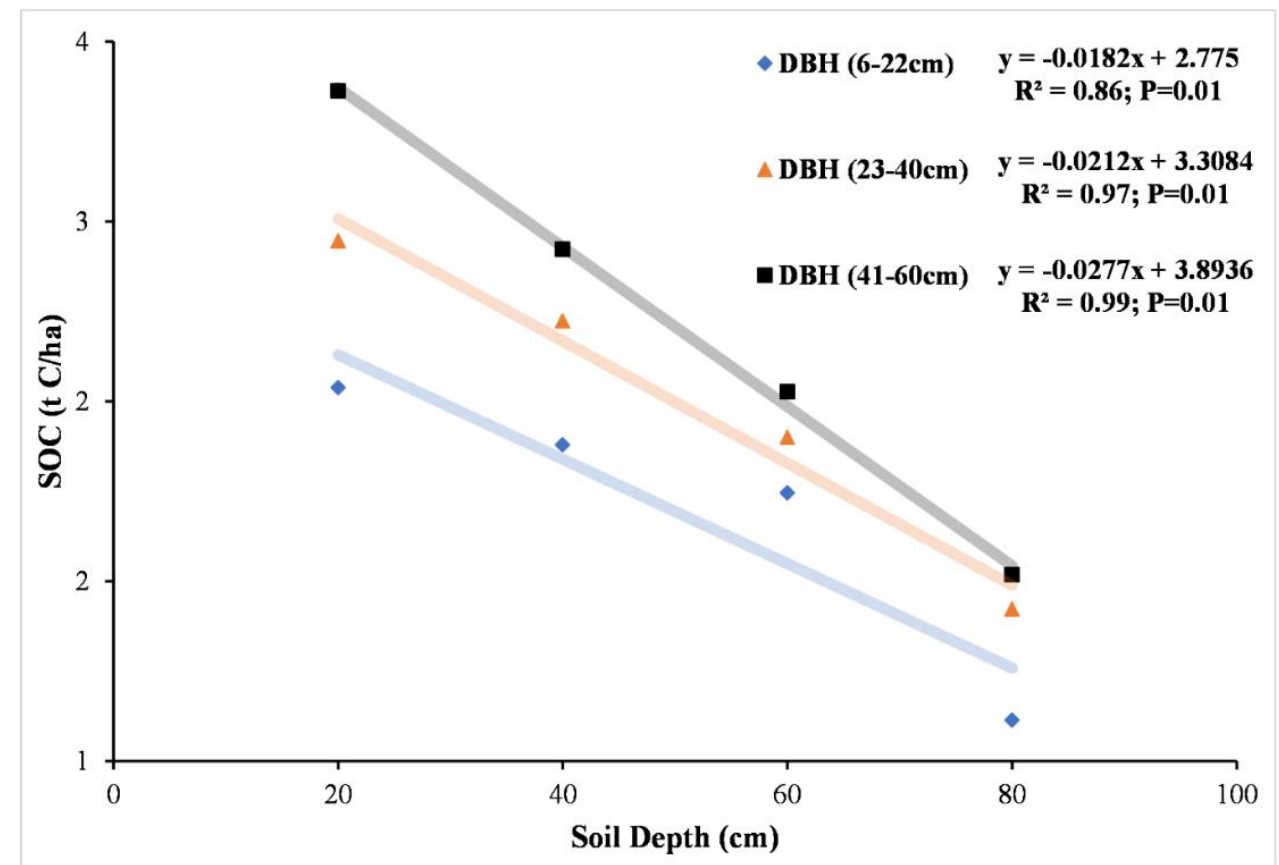

Figure 6. Relationship of soil organic carbon (SOC) with a soil depth of three different diameter classes $(6-22 \mathrm{~cm}, 23-40 \mathrm{~cm}, 41-60 \mathrm{~cm})$ of planted Pinus roxburghii stand at a significant level $(P=0.01)$

The research data found that there was a clear association between the diameter and the age of the tree, with the diameter being directly proportional to the age of the stand. The lower diameter $(8.47 \pm 2.21 \mathrm{~cm})$ has age $(6.83 \pm 1.79$ years $)$ and height $(3.82 \pm 0.97 \mathrm{~m})$, while the high diameter $(51.56 \pm 2.21 \mathrm{~cm})$ has age $(41.62 \pm 1.79$ years $)$ and height $(22.35 \pm 0.97 \mathrm{~m})$ in the study area. The relationship between diameter and age was $\left(\mathrm{y}=0.8071 \mathrm{x}+3 \mathrm{E}-14 ; \mathrm{R}^{2}=0.99\right)$ and between diameter and height was $\left(\mathrm{y}=0.4165 \mathrm{x}+0.4743 ; \mathrm{R}^{2}=0.88\right)$ respectively (Fig. 7).

The total standing carbon stock of planted $P$. roxburghii forest was $(59.86 \pm 8.62$ t C $\left.\mathrm{ha}^{-1}\right)$ with the highest value for the diameter $(41-60 \mathrm{~cm})($ Fig. 8). As the diameter class interval shifted from lower to the higher class, all carbon stock forms, including live tree, forest floor and soil, increased significantly with the highest total carbon stock value $\left(29.89 \pm 4.63 \mathrm{t} \mathrm{C} \mathrm{ha}^{-1}\right)$ for diameter class $(41-60 \mathrm{~cm})$. 


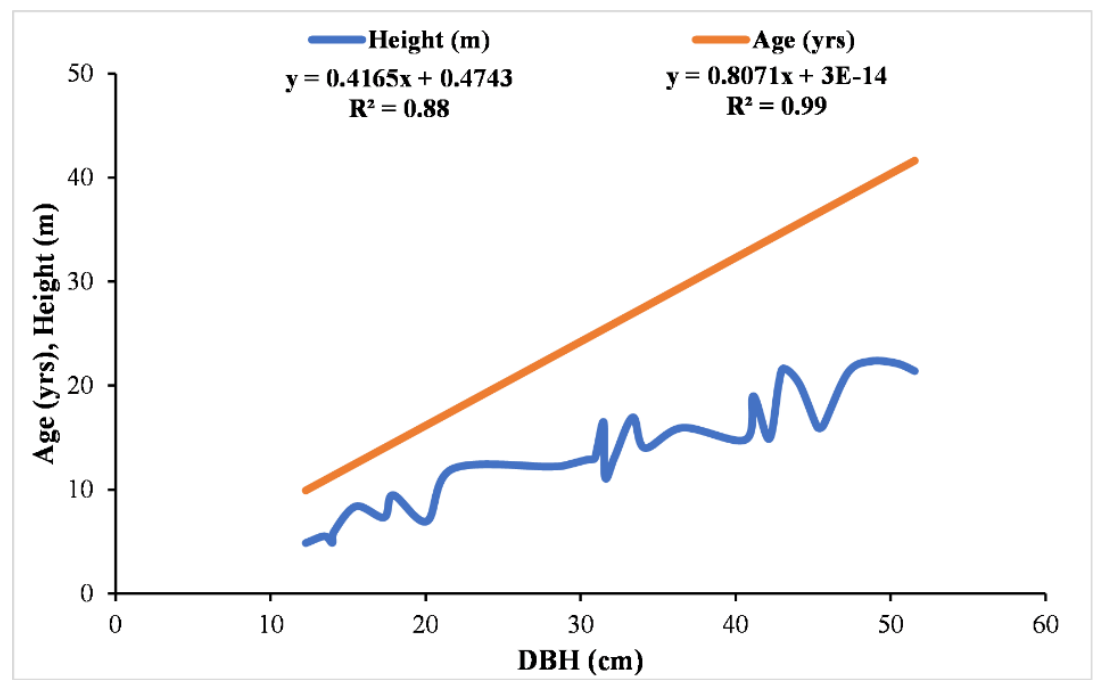

Figure 7. The relation between diameter classes versus age (yrs) and height ( $m$ )

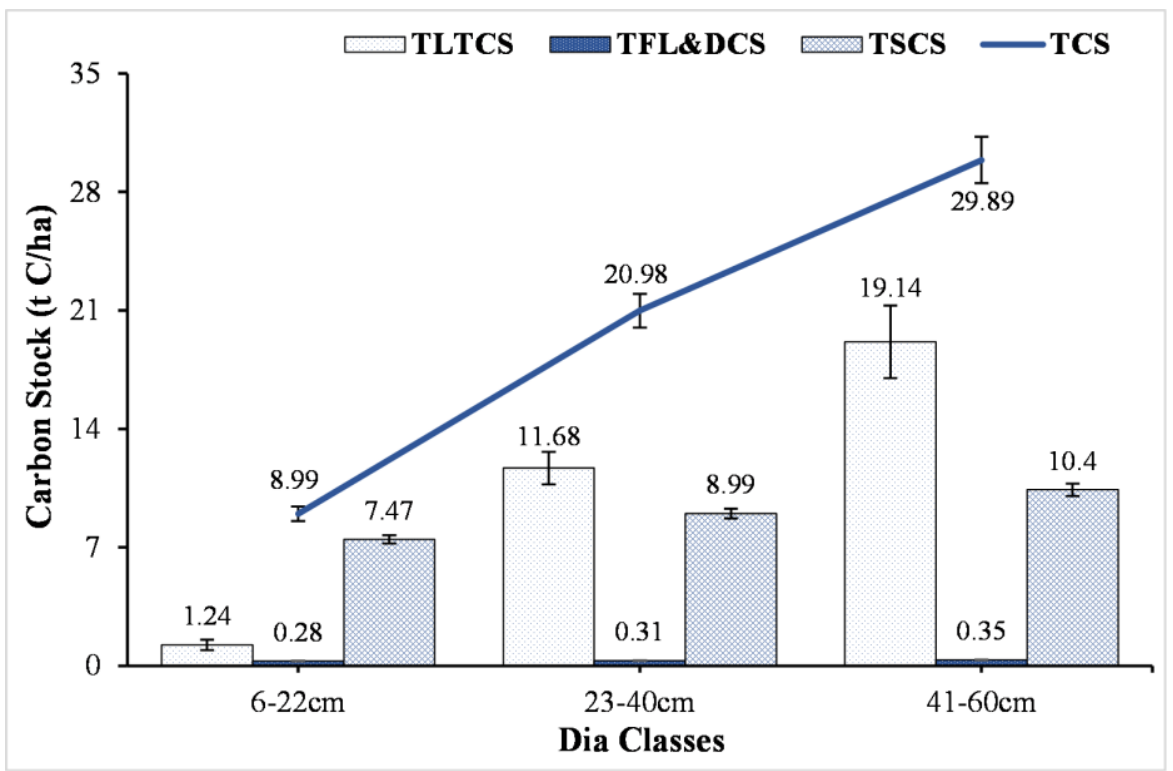

Figure 8. Carbon stock distribution pattern for three diameter classes of planted P. roxburghii forest. TLTCS = total live tree carbon stock, TFL\&DCS = total floor live and dead carbon stock, $T S C S=$ total soil carbon stock, TCS = total carbon stock

\section{Discussion}

In the present study, through investigating young planted $P$. roxburghii forest find out that stem density was maximum $\left(166.11 \pm 21.63\right.$ trees $\left.\mathrm{ha}^{-1}\right)$ for the diameter class $(23-40 \mathrm{~cm})$ and was minimum $\left(33.89 \pm 5.89\right.$ trees $\left.^{-1}\right)$ for diameter class $(41-60 \mathrm{~cm})$ as the diameter increases the stem density per hectare decreases significantly $(\mathrm{R} 2=0.54)$; which means that increased tree diameter results in the decrease of stem density (Nizami, 2012). The young planted stand volume has a positive association with the diameter with the highest volume $\left(16.69 \pm 4.64 \mathrm{~m}^{3} \mathrm{ha}^{-1}\right)$ for the diameter class (41$60 \mathrm{~cm}$ ); as the diameter increase, the stand volume increased significantly (Amir et al., 2018). 
Association between tree age and diameter was observed positive linear $\left(\mathrm{R}^{2}=0.99\right)$; our findings are in contrast with Siddiqui et al. (2013) that for conifer species age and diameter have significant association, and relationship between diameter and height was also observed positive linear $\left(\mathrm{R}^{2}=0.88\right)$ (Fig. 7), this finding is in line with the findings of Khan et al. (2016).

The current research found significant variation in the living tree biomass for three diameter classes of planted $P$. roxburghii forest. As the diameter increases with age, live tree biomass carbon of planted $P$. roxburghii also increases gradually. These findings are steady with Cao et al. (2012) and Li et al. (2013) that stand age/diameter effect the tree biomass carbon significantly.

With the increase in diameter, the overall tree growth variables effects significantly, i.e., in current studies, we found that out of three diameter classes, the highest diameter class $(41-60 \mathrm{~cm})$ has the highest values for basal area $\left(14.19 \pm 3.67 \mathrm{~m}^{2} \mathrm{ha}^{-1}\right)$, volume $\left(16.69 \pm 4.64 \mathrm{~m}^{3} \mathrm{ha}^{-1}\right)$, total tree biomass $\left(12.76 \pm 1.43 \mathrm{t} \mathrm{ha}^{-1}\right)$ and total live tree carbon stock $\left(19.14 \pm 2.15 \mathrm{t} \mathrm{C} \mathrm{ha}^{-1}\right)$. Recent studies are also in contrast with our findings increasing carbon stock throughout the different growth periods of trees (Peichl and Arain, 2006; En et al., 2012).

Trees can impact the heterogeneity and distribution of understory vegetation (Svenning and Skov, 2002). Due to its impacts on micro-environment, humus layer decomposition, soil moisture and forest management practices, forest stand configuration such as tree age and tree density has a high impact on understory vegetation. In every forest biome, the carbon content varies with different variables, such as decomposition rate, maintenance practices, tree types, and litter fertility (Kang et al., 2006).

In the below-ground biomass, we found out that grasses cover decreases with the increase in diameter class/age while litter and dead wood deposits accumulation increased significantly with the increase of diameter class/age. It could be because an increase in diameter, causing the increase in tree height and canopy, ultimately enhances natural pruning and shredding of leaves, due to this forest floor covered with dead leaves and wood, stopping the growth of grasses. This finding is inconsistent with the finding of Ming et al. (2014) that an increase in diameter ultimately increasing litter productivity.

The observed carbon stocking pattern for three different diameter classes was as follows: live tree $>$ Soil $>$ forest cover (Fig. 8). Our result is in association with (Amir et al., 2018) that living trees absorb and distill more carbon than some other foliage forms.

Comparing SOC with forest biomass is very difficult (Laganiere et al., 2010) since SOC can be influenced by different variables, such as standing age, tree types, the form of forest, environment, and chemical and physical properties of the soil (Mora et al., 2014; Wang et al., 2014).

As compared to deeper soil, the soil carbon was recorded higher in the topsoil of each diameter class stand. It may be attributed to SOC's development by decomposing the root system and litter that first reached the topsoil near the ground, as other studies have shown (Zhang et al., 2012). There was a negative correlation of soil carbon with different diameter classes at various depths, as soil carbon values tend to decline in depth. Furthermore, with the increase in diameter, the soil carbon value significantly increased; our results are in line with the findings of (Amir et al., 2019) that with the relevant stand diameter and soil depth, the mean soil carbon showed a decrease. 
Our study showed an increasing trend of soil carbon for different diameter classes as the highest value of SOC was obtained for the highest diameter class $(41-60 \mathrm{~cm})$. Besides this, litter and dead wood deposits were also recorded significantly high for the highest diameter class; Due to the deposition of organic matter in higher diameter stand, soil organic carbon typically increased with the stand age in conifer forest ( $\mathrm{Li}$ et al., 2013). According to facts and figures, our hypothesis sustained that young afforested plantations are also vital sources to sequester the carbon.

Global warming is one of the main issues for the current century, mainly caused due to greenhouse gases; for the reduction of greenhouse gases, there is a need to increase and enhance the sinks in biomass (Zhao et al., 2014). Moreover, the simplest and the best way is to plant trees; so, the afforestation could be the critical step to control global warming (Sharma et al., 2011; Misir et al., 2013). To minimize atmospheric CO2 emissions by sequestering carbon in soils, afforestation, and reforestation have been seen as necessary (Smal and Olszewska, 2008). While on the other side, afforestation can also play a pivotal role in increasing the forest area and ultimately result in mitigating the global warming issue by sequestrating more carbon contents in the form of the living tree, forest floor cover and soil; this idea is agreed with the proposed suggestions of the (Watson, 2000). So, planting trees is much better than planting nothing; increasing forest area is an effective way to reduce elevated atmospheric carbon (Taylor et al., 2007); as the tree increases its diameter, absorption capacity increases (Huy and Tuan, 2008). The mountain ranges of the Karakorum-Hindukush region in northwest Pakistan has great potential to sequester and sink atmospheric carbon dioxide.

\section{Limitations and uncertainties}

This research was performed using a field inventory approach to investigate biomass and carbon distribution trends through the planted P. roxburghii forest in Pakistan. For the whole stem (above ground) biomass calculation, we used fixed BEF value 1.51 following (IPCC, 2006). We used a root to shoot ratio $(R)$ of 0.19 (Amir et al., 2018). These values may vary with stand diameter/age; the present estimates of carbon allocation along the planted $P$. roxburghii may hold some qualms, which might tempt errors in carbon stock assessment along the diameter.

\section{Conclusion}

The present study showed a correlation between diameter and different tree growth factors and soil; as the diameter increases, all the mentioned factors increased significantly in a positive linear manner. There is a slight association of forest cover (grasses, litter and deadwood) with the diameter with the increase in diameter litter and deadwood accumulation increases while grasses cover decreases. Overall, the average carbon stocking values demonstrated the significant capacity for biomass and carbon sequestration during stand growth in the planted $P$. roxburghii. We further concluded that the proper management, increasing afforestation of bare land, and increasing vegetation cover in the region could increase carbon sequestration potential in the future. The conducted study may provide guidelines for managing pure planted $P$. roxburghii forest to enhance annual carbon potential based on growing and structure unique relationships. Current research has revealed that afforestation practice played an 
essential role in carbon sequestration, the amount of sequestration could be increased furthermore by adopting mixed forest stand, and for this purpose, Quercus spp could be used. Therefore, we strongly recommended that forests consider rehabilitation and sustainable management for forest restoration and conservation.

Acknowledgements. We would like to thanks the forest department of district Swat for assistance, thanks to Soil testing and Conservation Lab, Rawalpindi, Pakistan, for soil samples analysis. It was a selfsupported study.

\section{REFERENCES}

[1] Ahmad, A., Nizami, S. M. (2015): Carbon stocks of different land uses in the Kumrat valley, Hindu Kush Region of Pakistan. - Journal of Forestry Research 26(1): 57-64. https://doi.org/10.1007/s11676-014-0008-6.

[2] Ahmad, A., Mirza, N., Nizami, S. M. (2014a): Assessment of biomass and carbon stocks in coniferous forest of Dir Kohistan, KPK. - Pakistan Journal of Agricultural Sciences 51(2): 335-340. http://www.pakjas.com.pk/papers/2282.pdf.

[3] Ahmad, S., Ahmad, A., Moazzam, N. S. (2014b): Assessment of biomass expansion factor of Picea smithiana (Wall) Boiss. - Int. J. Sci. Eng. Res. 5(11): 1232-1239.

[4] Amir, M., Liu, X., Ahmad, A., Saeed, S., Mannan, A., Muneer, M. A. (2018): Patterns of biomass and carbon allocation across chronosequence of Chir pine (Pinus roxburghii) forest in Pakistan: inventory-based estimate. - Advances in Meteorology 8. https://doi.org/10.1155/2018/3095891.

[5] Amir, M., Saeed, S., Liu, X. D., Mannan, A., Khan, A., Li, Z. Z., Muneer, M. A. (2019): Soil organic content of stands of different ages in a subtropical chir pine (Pinus roxburghii) forest of Pakistan. - Applied Ecology and Environmental Research 17(5): 11475-11487. http://dx.doi.org/10.15666/aeer/1705_114751487.

[6] Arif, M., Shahzad, M. K., Elzaki, E. E. A., Hussain, A., Zhang, B., Yukun, C. (2017): Biomass and carbon stocks estimation in Chichawatni irrigated plantation in Pakistan. $\begin{array}{lllll}\text { Int } & \mathrm{J} & \text { Agric } & \text { Biol 1339-1349. }\end{array}$ http://www.fspublishers.org/published_papers/12397_.pdf.

[7] Baishya, R., Barik, S. K., Upadhaya, K. (2009): Distribution pattern of aboveground biomass in natural and plantation forests of humid tropics in northeast India. - Tropical ecology 50(2): 295. http://tropecol.com/pdf/open/PDF_50_2/J-10.pdf.

[8] Bauhus, J., Pokorny, B., van der Meer, P. J., Kanowski, P. J., Kanninen, M. (2010): Ecosystem goods and services-the key for sustainable plantations. - CIFOR 2010: 205227. https://www.cifor.org/publications/pdf_files/Books/BKanninen010208.pdf.

[9] Bonner, M. T. L., Schmidt., Shoo, L. P. (2013): A meta-analytical global comparison of aboveground biomass accumulation between tropical secondary forests and monoculture plantations. - Forest Ecology and Management 291: 73-86. https://doi.org/10.1016/j.foreco.2012.11.024.

[10] Canadell, J. G., Kirschbaum, M. U., Kurz, W. A., Sanz, M. J., Schlamadinger, B., Yamagata, Y. (2007): Factoring out natural and indirect human effects on terrestrial carbon sources and sinks. - Environmental Science \& Policy 10(4): 370-384. https://doi.org/10.1016/j.envsci.2007.01.009.

[11] Cao, J., Wang, X., Tian, Y., Wen, Z., Zha, T. (2012): Pattern of carbon allocation across three different stages of stand development of a Chinese pine (Pinus tabulaeformis) forest. - Ecological Research 27(5): 883-892. https://doi.org/10.1007/s11284-012-09651. 
[12] Chrsquo, H. Y., Ahmed, O. S., Majid, N. M. A. (2011): Assessment of soil carbon storage in a tropical rehabilitated forest. - International Journal of Physical Sciences 6(26): 6210-6219. https://doi.org/10.5897/IJPS11.076.

[13] Cossalter, C., Pye-Smith, C. (2003): Fast-Wood Forestry: Myths and Realities. Vol. 1. CIFOR, Bogor.

[14] Delmotte, M. V., Zhai, P., Pörtner, H. O., Roberts, D., Skea, J., Shukla, P. R., Pirani, A., Okia, M. W., Péan, C., Pidcock, R., Connors, S. (2018): An IPCC Special Report on the Impacts of Global Warming of 1.5 C. - https://www.cooperacionsuiza.pe/wpcontent/uploads/2018/03/3.reporte-especial-calentamiento-global-a-1.5c.pdf.

[15] En, L., Hui, W., Shi-rong, L. (2012): Characteristics of carbon storage and sequestration in different age beech (Castanopsis hystrix) plantations in south subtropical area of China. - Yingyong Shengtai Xuebao 23(2): 335-340.

[16] FAO (2006): Global Forest Resources Assessment 2005: Progress Towards Sustainable Forest Management.- FAO Forestry Paper 147. FAO, Rome.

[17] Gross, C. D., Harrison, R. B. (2018): Quantifying and comparing soil carbon stocks: underestimation with the core sampling method. - Soil Science Society of America Journal 82(4): 949-959. https://doi.org/10.2136/sssaj2018.01.0015.

[18] Holl, K. D., Zahawi, R. A. (2014): Factors explaining variability in woody aboveground biomass accumulation in restored tropical forest. - Forest Ecology and Management 319: 36-43. https://doi.org/10.1016/j.foreco.2014.01.024.

[19] Huy, B., Tuan, Ahn. P. (2008): Estimating CO2 sequestration in natural broad-leaved evergreen forests in Vietnam. - APA News (FAO) 32: 7-10.

[20] IPCC (2006): Intergovernmental Panel on Climate Change (IPCC) Guidelines for National Greenhouse Gas. - IPCC, Geneva.

[21] Kang, B., Liu, S., Zhang, G., Chang, J., Wen, Y., Ma, J., Hao, W. (2006): Carbon accumulation and distribution in Pinus massoniana and Cunninghamia lanceolata mixed forest ecosystem in Daqingshan, Guangxi, China. - Acta Ecologica Sinica 26(5): 13201327. https://doi.org/10.1016/S1872-2032(06)60024-3.

[22] Khan, M. S., Khan, S., Shah, W., Hussain, A., Masaud, S. (2016): Height growth, diameter increment and age relationship response to sustainable volume of subtropical Chir pine (Pinus roxburghii) forest of Karaker Barikot forest. - Pure and Applied Biology 5(4): 1. http://dx.doi.org/10.19045/bspab.2016.50095.

[23] Laganiere, J., Angers, D. A., Pare, D. (2010): Carbon accumulation in agricultural soils after afforestation: a meta-analysis. - Global Change Biology 16(1): 439-453. https://doi.org/10.1111/j.1365-2486.2009.01930.x.

[24] Laurance, W. F. (2007): A new initiative to use carbon trading for tropical forest conservation. - Biotropica 39(1): 20-24. https://doi.org/10.1111/j.17447429.2006.00229.x.

[25] Li, C., Zha, T., Liu, J., Jia, X. (2013): Carbon and nitrogen distribution across a chronosequence of secondary lacebark pine in China. - The Forestry Chronicle 89(2): 192-198. https://doi.org/10.5558/tfc2013-037.

[26] Ming, A., Jia, H., Zhao, J., Tao, Y., Li, Y. (2014): Above-and below-ground carbon stocks in an indigenous tree (Mytilaria laosensis) plantation chronosequence in $\begin{array}{lllll}\text { subtropical China. } & - & \text { PLoS ONE } & \text { 9(10): }\end{array}$ https://doi.org/10.1371/journal.pone.0109730.

[27] Misir, M., Misir, N., Bayburtlu, S., Bilgili, F. (2013): The yield of natural trembling aspen (Populus tremula L.) Stands (Northern and Eastern Anatolia). - Pakistan Journal of Agricultural Sciences 50(4): 537-547. http://pakjas.com.pk/papers/2190.pdf.

[28] Mora, J. L., Guerra, J. A., Armas-Herrera, C. M., Arbelo, C. D., Rodríguez-Rodríguez, A. (2014): Storage and depth distribution of organic carbon in volcanic soils as affected by environmental and pedological factors. - Catena 123: 163-175. https://doi.org/10.1016/j.catena.2014.08.004. 
[29] Nizami, S. M. (2012): The inventory of the carbon stocks in subtropical forests of Pakistan for reporting under Kyoto Protocol. - Journal of Forestry Research 23(3): 377384. https://doi.org/10.1007/s11676-012-0273-1.

[30] Nizami, S. M., Mirza, S. N., Livesley, S., Arndt, S., Fox, J. C., Khan, I. A., Mahmood, T. (2009): Estimating carbon stocks in sub-tropical pine (Pinus roxburghii) forests of Pakistan. - Pakistan Journal of Agricultural Sciences 46(4): 266-270. http://pakjas.com.pk/papers/78.pdf.

[31] Pan, Y., Luo, T., Birdsey, R., Hom, J., Melillo, J. (2004): New estimates of carbon storage and sequestration in China's forests: effects of age-class and method on inventory-based carbon estimation. - Climatic Change 67(2-3): 211-236. https://doi.org/10.1007/s10584-004-2799-5.

[32] Pearson, T. R. (2007): Measurement Guidelines for the Sequestration of Forest Carbon Vol. 18. - US Department of Agriculture, Forest Service, Northern Research Station, Washington, DC.

[33] Peichl, M., Arain, M. A. (2006): Above-and belowground ecosystem biomass and carbon pools in an age-sequence of temperate pine plantation forests. - Agricultural and Forest Meteorology 140(1-4): 51-63. https://doi.org/10.1016/j.agrformet.2006.08.004.

[34] Roy, J., Mooney, H. A., Saugier, B. (2001): Terrestrial Global Productivity. - Academic Press, San Diego.

[35] Saeed, S., Ashraf, M. I., Ahmad, A., Rahman, Z. (2016): The Bela forest ecosystem of district Jhelum, a potential carbon sink. - Pakistan Journal of Botany 48(1): 121-129.

[36] Sharma, C. M., Gairola, S., Baduni, N. P., Ghildiyal, S. K., Sarvesh, S. (2011): Variation in carbon stocks on different slope aspects in seven major types of temperate region of Garhwal Himalaya. - India. J. Biosci. 36(4): 701-708. https://doi.org/10.1007/s12038011-9103-4.

[37] Siddiqui, M. F., Shaukat, S. S., Ahmed, M., Khan, N., Khan, I. A. (2013): Age and growth rates of dominant conifers from moist temperate areas of Himalayan and Hindukush region of Pakistan. - Pak. J. Bot. 45(4): 1135-1147.

[38] Smal, H., Olszewska, M. (2008): The effect of afforestation with Scots pine (Pinus silvestris L.) of sandy post-arable soils on their selected properties. II. Reaction, carbon, nitrogen and phosphorus. - Plant and Soil 305(1-2): 171-187. https://doi.org/10.1007/s11104-008-9538-z.

[39] Sullivan, M. J., Talbot, J., Lewis, S. L., Phillips, O. L., Qie, L., Begne, S. K., Chave, J., Cuni-Sanchez, A., Hubau, W., Lopez-Gonzalez, G., Miles, L. (2017): Diversity and carbon storage across the tropical forest biome. - Scientific Reports 7(1): 1-12. https://doi.org/10.1038/srep39102.

[40] Svenning, J. C., Skov, F. (2002): Mesoscale distribution of understorey plants in temperate forest (Kalø, Denmark): the importance of environment and dispersal. - Plant Ecology 160(2): 169-185. https://doi.org/10.1023/A:1015885321263.

[41] Taylor, A. R., Wang, J. R., Chen, H. Y. (2007): Carbon storage in a chronosequence of red spruce (Picea rubens) forests in central Nova Scotia, Canada. - Canadian Journal of Forest Research 37(11): 2260-2269. https://doi.org/10.1139/X07-080.

[42] Ullah, S., Muhammad, B., Amin, R., Abbas, H., Muneer, M. (2019): Sensitivity of arbuscular mycorrhizal fungi in old-growth forests: direct effect on growth and soil carbon storage. - Appl. Ecol. Environ. Res. 17: 13749-13758. http://dx.doi.org/10.15666/aeer/1706_1374913758.

[43] Walkley, A., Black, J. B. (1934): An examination of the Degtjareff method for determining soil organic matter and proposed modification of the chromic titration method. - Soil Science 37(1): pp29-38.

[44] Wang, D., Wang, B., Niu, X. (2014): Forest carbon sequestration in China and its benefits. - Scandinavian Journal of Forest Research 29(1): 51-59. https://doi.org/10.1080/02827581.2013.856936. 
[45] Watson, R. T., Noble, I. R., Bolin, B., Ravindranath, N. H., Verardo, D. J., Dokken, D. J. (2000): Land Use, Land-Use Change and Forestry. A Special Report of the IPCC. Cambridge University Press, Cambridge.

[46] Winjum, J. K., Schroeder, P. E. (1997): Forest plantations of the world: their extent, ecological attributes, and carbon storage. - Agricultural and Forest Meteorology 84(1-2): 153-167. https://doi.org/10.1016/S0168-1923(96)02383-0.

[47] Zhang, H., Guan, D., Song, M. (2012): Biomass and carbon storage of eucalyptus and acacia plantations in the Pearl River Delta, South China. - Forest Ecology and Management 277: 90-97. https://doi.org/10.1016/j.foreco.2012.04.016.

[48] Zhao, J., Kang, F., Wang, L., Yu, X., Zhao, W., Song, X. et al. (2014): Patterns of biomass and carbon distribution across a chronosequence of Chinese pine (Pinus $\begin{array}{llllll}\text { tabulaeformis) } \quad \text { forests. } & - & \text { PLoS } & \text { ONE 94966. }\end{array}$ https://doi.org/10.1371/journal.pone.0094966.

\section{APPENDIX}

Table A1. Data of sampling plots (with reference to Figure 1)

\begin{tabular}{c|c|c|c|c|c|c}
\hline Plot no & Elevation $(\mathbf{m})$ & Latitude & Longitude & Tree density & Slope & Aspect \\
\hline 1 & 1180 & 34.971 & 72.21 & 20 & $44 \%$ & Eastern \\
2 & 1222 & 34.947 & 72.206 & 43 & $58 \%$ & Northern \\
3 & 1232 & 34.912 & 72.174 & 11 & $60 \%$ & Southern \\
4 & 1229 & 34.883 & 72.274 & 13 & $60 \%$ & Southern \\
5 & 1193 & 34.855 & 72.179 & 33 & $52 \%$ & Northern \\
6 & 1148 & 34.882 & 72.204 & 24 & $34 \%$ & Northern \\
7 & 1231 & 34.923 & 72.279 & 36 & $54 \%$ & Northern \\
8 & 1274 & 34.928 & 72.236 & 15 & $78 \%$ & Eastern \\
9 & 1286 & 34.84 & 72.248 & 10 & $56 \%$ & Southern \\
10 & 1273 & 34.847 & 72.269 & 21 & $79 \%$ & Western \\
11 & 1191 & 34.799 & 72.236 & 18 & $37 \%$ & Eastern \\
12 & 1235 & 34.765 & 72.24 & 26 & $50 \%$ & Northern \\
13 & 1259 & 34.798 & 72.28 & 28 & $63 \%$ & Northern \\
14 & 1294 & 34.799 & 72.311 & 31 & $51 \%$ & Southern \\
15 & 1348 & 34.831 & 72.323 & 25 & $80 \%$ & Northern \\
16 & 1390 & 34.819 & 72.366 & 8 & $84 \%$ & Southern \\
17 & 1376 & 34.832 & 72.416 & 19 & $79 \%$ & Western \\
18 & 1301 & 34.872 & 72.357 & 24 & $80 \%$ & Eastern \\
\hline
\end{tabular}

